\title{
Paragraphs in Classical Latin Texts: Problems with Editing and the Internal Evidence from Texts
}

\author{
Michal Ctibor
}

\begin{abstract}
The present article deals with the question of paragraphs in classical Latin texts. In the first half, it presents and illustrates two major problems that can arise from an editor's careless division of a text into paragraphs (i.e. change in reference of anaphoric pronouns; misleading text segmentation). In the second half, the article claims and tries to prove (largely on the basis of the inner characteristics of texts) that ancient authors (or at least auctor ad Herennium, Cicero, Sallust, and Suetonius) structured their texts into paragraphs, though they used various other means than indentation to signal it to the reader.
\end{abstract}

\section{Keywords}

claim and evidence; discourse structure; paragraph; paragraph of definitions; Suetonius; text scheme; text segmentation

This study was supported by the Charles University project Progres 4, Language in the shiftings of time, space, and culture. 


\section{Introduction}

In modern editions of ancient texts, there is typically more than one line of text segmentation into paragraphs: namely three independent lines in Cicero (Arabic numerals, Roman numerals, and indentation) and two independent lines in other prose authors (numerals and indentation); these lines frequently propose partially or substantially different segmentation. Cf. (1), where there are the Roman numerals (31), Arabic numerals (XI) and indentation (each of them proposing a different segmentation).

(1) [...] Ad iudicem sic, sed ego apud parentem loquor: "errauit, temere fecit, paenitet; ad clementiam tuam confugio, delicti ueniam peto, ut ignoscatur oro."

Si nemo impetrauit, adroganter; si plurimi, tu idem fer opem, qui spem dedisti. 31 . An sperandi Ligario causa non sit, cum mihi apud te locus sit etiam pro altero deprecandi? Quamquam nec in hac oratione spes est posita causae nec in eorum studiis, qui a te pro Ligario petunt, tui necessarii. XI. Vidi enim et cognoui $[\ldots]$

'[...] That is the tone to use to a jury, but I plead before a father: "He blundered, he acted thoughtlessly, he is sorry; I throw myself upon your clemency, I crave indulgence for his fault, I implore his pardon."

If no one has pleaded for that successfully, it is presumption; if very many, than grant help, even as you have given hope. 31. Or is Ligarius to have no ground for hope, when to me grace is granted to beg in your presence for mercy for another also? And yet it is not on this appeal of mine that I build my hopes of success; no, nor yet on the efforts of those friends of yours who make their suit to you on Ligarius's behalf. XI. For I have seen and learnt, [...]'

(Cic. Lig. 30-31).

Moreover, the indentation frequently varies from one edition to another. As a result, the reader may conclude that the segmentation which is suggested in editions cannot be trusted, and - possibly - even that ancient texts simply were not meant to be segmented the way we are familiar with.

The present article pursues two aims. In the first part, I would like to show how indentation can influence the meaning and reading of the text (with the inference that indenting is not a mechanical, but rather interpretative and an editor should work with it carefully). In the second part, I will try to show that there are certain recursive paragraph patterns which, in my opinion, prove that ancient authors, or at least those whose text I quote in this article, wrote their texts with paragraphs in mind and that these patterns can serve as cues for delimiting paragraphs in modern editions. I, thus, try to offer the text-internal evidence for existence of paragraphs. ${ }^{1}$

1 For a discussion of text-external (historical, i.e. extant graphical means) evidence see Wingo (1972). Textexternal evidence is not essentially connected to the production of the text, it just accompanies the text. In contrast, text-internal evidence is based on the wording of the text. 


\section{Problems with paragraphs in editions}

Paragraphs can be sources of at least two major problems: firstly, the editor's division of a text into paragraphs can influence (or, more precisely, strongly suggest) the reference of anaphoric pronouns; secondly, it can obscure the structure of the text (though the raison d'etre of the paragraphs is precisely the opposite: to make the structure of the text more transparent for the reader and easier to recognize).

Let us first take a look at the beginning of the Life of Augustus by Suetonius, given in (2). I have taken the text from the Loeb Classical Library (ed. Rolfe) and have underlined the part that I am going to discuss below.

1. Gentem Octaviam Velitris praecipuam olim fuisse multa declarant. Nam et vicus celeberrima parte oppidi iam pridem Octavius vocabatur et ostendebatur ara Octavio consecrata, qui bello dux [...]. Decretum etiam publicum exstabat, [...]

2. Ea gens a Tarquinio Prisco rege inter minores gentis adlecta in senatum, mox a Servio Tullio in patricias traducta, procedente tempore ad plebem se contulit ac rursus magno intervallo per Divum Iulium in patriciatum redit. Primus ex hac magistratum populi suffragio cepit C. Rufus. [...] Proavus Augusti secundo Punico bello stipendia in Sicilia tribunus militum fecit Aemilio Papo imperatore. Avus municipalibus magisteriis contentus abundante patrimonio tranquillissime senuit. Sed haec alii; ipse Augustus nihil amplius quam equestri familia ortum se scribit vetere ac locuplete, et in qua primus senator pater suus fuerit. M. Antonius libertinum ei proavum exprobrat, restionem e pago Thurino, avum argentarium. Nec quicquam ultra de paternis Augusti maioribus repperi.

'There are many indications that the Octavian family was in days of old a distinguished one at Velitrae; for not only was a street in the most frequented part of town long ago called Octavian, but an altar was shown there besides, consecrated by an Octavius. This man was leader in a war [...] There was, besides, a decree of the people on record $[\ldots]$

The family was admitted to the senate by king Tarquinius Priscus among the lesser clans; was later enrolled by Servius Tullius among the patricians; in course of time returned to the ranks of the plebeians; and after a long interval was restored to patrician rank by the Deified Julius. The first of the house to be elected by the people to a magistracy was Gaius Rufus, who became quaestor. [...] Augustus's great-grandfather served in Sicily in the second Punic war as tribune of the soldiers under the command of Aemilius Papus. His grandfather, content with the offices of a municipal town and possessing an abundant income, lived to a peaceful old age. This is the account given by others; Augustus himself merely writes that he came of an old and wealthy equestrian family, in which his own father was the first to become a senator. Marcus Antonius taunts him with his great-grandfather, saying that he was a freedman and a rope-maker from the country about Thurii, while his grandfather was a money-changer. This is all that I have been able to learn about the paternal ancestors of Augustus.'

(Suet. Aug. 1-2). 
In (2), Suetonius shows first that the gens Octavia must have been famous in its original municipality and he gives information about the most ancient and most prominent scions of the gens. Then, the crucial sentence with the anaphoric pronoun sed haec alii comes. The reference of haec is influenced (or, more precisely, is strongly suggested) by the paragraph segmentation. This point can be demonstrated by comparing two editions: ed. Rolfe and ed. Carter, see (3) and (4) below. Rolfe sticks to the canonical numbering and indents where the Arabic numerals occur: he, thus, strongly suggests that we take haec as referring only to the passage ea gens [...] senuit. In contrast, Carter decides to take everything that precedes the sentence sed haec alii as a single paragraph and makes this sentence the first sentence of the second paragraph; by this paragraph segmentation he strongly suggests that we take haec as referring to the passage Gentem Octaviam [...] senuit. The varying (implied) reference of haec is printed in italics in (3) and (4).

(3) ed. Rolfe

1. Gentem Octaviam Velitris praecipuam olim fuisse multa declarant. Nam et vicus celeberrima parte oppidi iam pridem Octavius vocabatur $[\ldots]$

2. Ea gens a Tarquinio Prisco rege inter minores gentis adlecta in senatum, mox a Servio Tullio in patricias traducta, procedente tempore ad plebem se contulit, [...] senuit. $\underline{\text { Sed }}$ haec alii; ipse Augustus nihil amplius quam equestri familia ortum se scribit $[\ldots]$
(4) ed. Carter

1. Gentem Octaviam Velitris praecipuam olim fuisse multa declarant. Nam et vicus celeberrima parte oppidi iam pridem Octavius vocabatur [...] 2. Ea gens a Tarquinio Prisco rege inter minores gentis adlecta in senatum, mox a Servio Tullio in patricias traducta, procedente tempore ad plebem se contulit, [...] senuit.

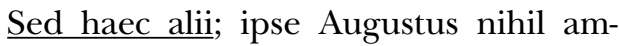
plius quam equestri familia ortum se scribit $[\ldots]$

For several reasons, I would prefer the traditional solution (ed. Rolfe). I admit that this is subjective and others may follow Carter; in any case, however, one of the solutions is incorrect and suggests an incorrect reference of haec. This is the point. Which solution is correct, that may be subject to debate.

The second and much more frequent problem which is brought about by incorrect paragraph segmentation is that the structure of the text is obscured. To find an example, we do not have to go further than to the canonical paragraphs 3 and 4 of the Life of Augustus. These two paragraphs clearly deal with Augustus's father and with his maternal origin (his mother and her family), respectively. But the canonical paragraphs (as well as Rolfe) misplace the last sentence of the third paragraph and make it the first sentence of paragraph 4. This sentence deals with the death of C. Octavius pater and should naturally conclude paragraph 3 , which focuses on his life. Yet, in most editions, it opens up paragraph 4 on Atia mater and her relatives. The reason for this misplacement may be the repetition of the name Atia in the sentence in question and in the following one (possibly giving a false impression that these two sentences both give information on Atia) as well as the preceding short digression to Cicerones. Cf. (5), where the sentence in question is underlined. 
3. C. Octavius pater a principio aetatis et re et existimatione magna fuit [...]; amplis enim innutritus opibus, honores et adeptus est facile et egregie administravit. Ex praetura Macedoniam sortitus, fugitivos, residuam Spartaci et Catilinae manum, Thurinum agrum tenentis in itinere delevit, negotio sibi in senatu extra ordinem dato. Provinciae praefuit non minore iustitia quam fortitudine; namque Bessis ac Thracibus magno proelio fusis ita socios tractavit, ut epistulae M. Ciceronis exstent quibus Quintum fratrem [...] monet, imitetur in promerendis sociis vicinum suum Octavium.

4. Decedens Macedonia, prius quam profiteri se candidatum consulatus posset, mortem obiit repentinam, superstitibus liberis Octavia maiore, quam ex Ancharia, et Octavia minore item Augusto, quos ex AтіA tulerat. Aтіа M. Atio Balbo et Iulia, sorore C. Caesaris, genita est. Balbus, paterna stirpe Aricinus, multis in familia senatoriis imaginibus, a matre Magnum Pompeium artissimo contingebat gradu, functusque honore praeturae inter vigintiviros agrum Campanum plebi Iulia lege divisit. [...]

'His father Gaius Octavius was from the beginning of his life a man of wealth and repute, [...]; for as a matter of fact, being brought up in affluence, he readily attained to high positions and filled them with distinction. Macedonia fell to his lot at the end of his praetorship; on his way to the province, executing a special commission from the senate, he wiped out a band of runaway slaves, refugees from the armies of Spartacus and Catiline, who held possession of the country about Thurii. In governing his province he showed equal justice and courage; for besides routing the Bessi and the other Thracians in a great battle, his treatment of our allies was such, that Marcus Cicero, in letters which are still in existence, urges and admonishes his brother Quintus, [...] to imitate his neighbor Octavius in winning the favour of our allies.

While returning from Macedonia, before he could declare himself a candidate for the consulship, he died suddenly, survived by three children, an elder Octavia by Anacharia, and by Atia a younger Octavia and Augustus. Atia was the daughter of Marcus Atius Balbus and Julia, sister of Gaius Caesar. Balbus, a native of Aricia on his father's side, and of a family displaying many senatorial portraits, was closely connected on his mother's side with Pompey the Great - After holding the office of praetor, he was one of the commission of twenty appointed by the Julian law to distribute lands in Campania to the commons. [...]'

(Suet. Aug. 3-4).

Carter came up with a solution different not only from that of the canonical paragraphs and Rolfe (quoted in (5)) but also from the one I propose (making the first sentence of paragraph 4 the last sentence of the paragraph 3): Carter joins the canonical paragraphs 3 and 4 into a single paragraph. This seems, at first sight, a legitimate option: Carter decides to create a larger paragraph on Augustus's parents. In the given context, however, this solution is not preferable: the paternal origin (gens Octavia) was already dealt with in paragraph 2, so what is the reason for joining the passage on Augustus's father to the passage on Augustus's mother and his maternal origin? If we are about 
to subordinate the passage on Gaius Octavius pater to some larger paragraph, it should be that on Augustus's paternal origin (paragraph 2). In my opinion, however, Gaius Octavius is given such prominence here that the passage should stand independently as a paragraph. I believe, thus, the structure of the beginning of the Life of Augustus to be as follow: paragraph 1 - prominence of gens Octavia in Velitri; paragraph 2 - paternal ancestors of Augustus; paragraph 3 - father; paragraph 4 - mother and her relatives.

\section{Did the ancient authors write in paragraphs?}

In section 2, I focused on the problems that occur when editors segment a text into paragraphs: when they do it, they should do it with careful consideration. But should they do it at all? Is there any support for such a treatment of texts in the texts themselves? Were ancient texts written in paragraphs which just happened not to be graphically marked (indented), or were they structured differently?

\subsection{Structured information}

One of the main arguments for the claim that ancient authors did write in paragraphs is the fact that information in ancient texts is usually carefully organized. Let's take a look at the passage in (6):

(6) Graves ignominias cladesque duas omnino nec alibi quam in Germania accepit, Lollianam et Varianam, sed Lollianam maioris infamiae quam detrimenti, Varianam paene exitiabilem, tribus legionibus cum duce legatisque et auxiliis omnibus caesis. Hac nuntiata excubias per urbem indixit, ne quis tumultus existeret, et praesidibus provinciarum propagavit imperium, ut a peritis et assuetis socii continerentur. Vovit et magnos ludos Iovi Optimo Maximo [...]

'He suffered but two severe and ignominious defeats, those of Lollius and Varus, both of which were in Germany. Of these the former was more humiliating than serious, but the latter was almost fatal, since three legions were cut to pieces with their general, his lieutenants, and all the auxiliaries. When the news of this came, he ordered that watch be kept by night throughout the city, to prevent outbreak, and prolonged the terms of the governors of the provinces, that the allies might be held to their allegiance by experienced men with whom they were acquainted. He also vowed great games to Jupiter Optimus Maximus [...]'

(SuEt. Aug. 23).

In order to represent the information structure of a paragraph, I use the following method of questions and answers: first I ask for the discourse topic of the paragraph; then I ask for all the focuses which follow. ${ }^{2}$ Whenever the topic is modified (narrowed,

2 I use the terms "topic" and "focus" as is common in Functional Grammar, cf. Spevak (2010: pp. 6-7) or Hoffmann (2010: pp. 268-269). For question tests see Spevak (2010: pp. 35-36). 
split into more subtopics, etc. $)^{3}$ I make a greater indentation. ${ }^{4}$ The representation of the information structure of (6) looks like this:

WHAT IS THE TOPIC OF THE PRESENT PARAGRAPH? (graves ignominias cladesque) ${ }^{5}$

What CAN WE SAY ABOUT HIS DEFEATs? (duas accepit, in Germania)

WHICH TWO? (Lolianam et Varianam)

WHAT CAN WE SAY OF LOLIANA? (maioris infamiae quam detrimenti)

What Can We Say of Variana? (paene exitiabilem [...])

What followed after Variana? (1. indixit 2. et propagavit. 3. Vovit et. [...])

When Suetonius set about writing this passage he certainly had to have in his mind all the information structured from the general to the particular (I deduce this from the result of his writing, i.e. the extant text). Such an organization (structuration) of information is, in my opinion, the very thing which should be called a paragraph.

\subsection{Text schemes}

Another main argument for the claim that ancient authors wrote in paragraphs is the fact that we can find text schemes which appear repeatedly in the works of one author or even of several authors. Below, I present two text schemes.

\subsubsection{Text scheme 1: Paragraph of definitions}

I call the first text scheme "Paragraph of definitions" because it is used where the author wishes to define several things belonging to one class. Its schematic representation looks like this:

There are $\mathrm{X}$ things of one class: $1,2,3,4$.

1 is something.

2 is something.

3 is something.

4 is something.

To put it in words, such a paragraph starts with a claim that there are several types of things belonging to the same class; these are usually enumerated $(1,2,3,4)$. Then, the types are defined, item-by-item. Examples of such a paragraph are given in (7)-(9).

3 For more on so-called "Thematic Progression", see Daneš (1968). For the relations between "Thematic Progression" and the study of paragraphs, see Daneš (1994).

4 Also Kroon (2011: p. 189) or Blommaert (2009: pp. 88ff.) use the greater indentation to represent the discourse structure.

5 The object in the first position of a sentence is typically the topic of the sentence, cf. Hoffmann (2010: pp. 270-274). 
(7) Oportet igitur esse in oratore inventionem, dispositionem, elocutionem, memoriam, pronuntiationem.

$\underline{\text { Inventio }}$ est excogitatio rerum verarum aut veri similium quae causam probabilem reddant.

Dispositio est ordo et distributio rerum, quae demonstrat, quid quibus locis sit conlocandum.

Elocutio est idoneorum verborum et sententiarum ad inventionem accomodatio.

Memoria est firma animi rerum et verborum et dispositionis perceptio.

Pronuntiatio est vocis, vultus, gestus moderatio cum venustate.

'The speaker, then, should possess the faculties of Invention, Arrangement, Style, Memory, and Delivery. Invention is the devising of matter, true or plausible, that would make the case convincing. Arrangement is the ordering and distribution of the matter, making clear place to which each thing is to be assigned. Style is the adaptation of suitable words and sentences to the matter devised. Memory is the firm retention in the mind of the matter, words, and arrangement. Delivery is the graceful regulation of voice, countenance, and gesture.'

(RHeT. Her. 1,3).

(8) Haec omnia tribus rebus adsequi poterimus: arte, imitatione, exercitatione.

Ars est praeceptio, quae dat certam viam rationemque dicendi.

Imitatio est qua impellimur, cum diligenti ratione, ut aliquorum similes in dicendo valeamus esse.

Exercitatio est adsiduus usus consuetudoque dicendi.

'All these faculties we can acquire by three means: Theory, Imitation, and Practice. By theory is meant a set of rules that provide a definite method and system of speaking. Imitation stimulates us to attain, in accordance with a studied method, the effectiveness of certain models in speaking. Practice is assiduous exercise and experience in speaking.'

(RHET. Her. 1,3).

(9) Ut nostri augures publici disserunt, agrorum sunt genera quinque: Romanus, Gabinus, peregrinus, hosticus, incertus.

Romanus dictus unde Roma ab Romulo;

Gabinus ab oppido Gabiis;

peregrinus ager pacatus, qui extra Romanum et Gabinum, quod uno modo in his servantur auspicia; dictus peregrinus a pergendo, id est a progrediendo: eo enim ex agro Romano primum progrediebantur: quocirca Gabinus quoque peregrinus, sed quod auspicia habet singularia, ab reliquo discretus;

hosticus dictus ab hostibus;

incertus is, qui de his quattuor qui sit ignoratur.

'As our State Augurs set forth, there are five kinds of fields: Roman, Gabine, peregrine, hostic, uncertain. "Roman" field-land is so called from Romulus, from whom Rome got its name. "Gabine" is named from the town Gabii. The "peregrine" is 
field-land won in war and reduced to peace, which is apart from the Roman and the Gabine, because in these latter the auspices are observed in one uniform manner: "peregrine" is named from pergere "to go ahead", that is, from progredi "to advance"; for into it their first advance was made out of the Roman field-land. By the same reasoning, the Gabine also is peregrine, but because it has auspices of its own special sort it is held separate from the rest. "Hostic" is named from the hostes "enemies". "Uncertain" field-land is that of which it is not known to which of these four classes it belongs.'

(VAR. ling. 5,33).

\subsubsection{Text scheme 2: Claim and evidence}

I call the second text scheme "Claim and evidence" because it is a scheme used where the author begins the paragraph with a general claim and then defends it by presenting particular instances. Its schematic representation looks like this:

General claim

$$
\begin{aligned}
& \mathrm{NAM}+1^{\text {st }} \text { argument/example } \\
& \mathrm{ET}+2^{\text {nd }} \text { argument/example } \\
& \mathrm{ET}+3^{\text {rd }} \text { argument/example }
\end{aligned}
$$

The first argument/example is frequently introduced by nam or its near-synonyms (enim, ${ }^{6}$ quippe, etc.). The other arguments/examples are frequently introduced by connectors and particles such as et, -que, at, atque, sed, etiam, porro, deinde, item, denique, etc., sometimes also by asyndeton. An example is given in (10) below. To the same type belongs also Suet. Aug. 1 quoted above.

(10) Liberalitatem omnibus ordinibus per occasiones frequenter exhibuit.

Nam et invecta urbi Alexandrino triumpho regia gaza tantam copiam nummariae rei effecit, ut faenore deminuto plurimum agrorum pretiis accesserit,

et postea, quotiens ex damnatorum bonis pecunia superflueret, usum eius gratuitum iis, qui cavere in duplum possent, ad certum tempus indulsit.

[Ø] Senatorum censum ampliavit ac pro octingentorum milium summa duodecies sestertium taxavit supplevitque non habentibus.

[Ø] Congiaria populo frequenter dedit, sed diversae fere summae: [...]

Frumentum quoque in annonae difficultatibus saepe levissimo, interdum nullo pretio viritim admensus est tesserasque nummarias duplicavit.

'He often showed generosity to all classes when occasion offered. For example, by bringing the royal treasures to Rome in his Alexandrian triumph he made ready money so abundant, that the rate of interest fell, and the value of real estate rose greatly; and after that, whenever there was an excess of funds from the property of those who had been condemned, he loaned it without interest for fixed periods

6 I call enim a near-synonym of nam pace Kroon (1995; 2011 and elsewhere), who argues for an essential difference between both particles ( am being a connector, enim being an interactional particle). 
to any who could give security for double the amount. He increased the property qualification for senators, requiring one million two hundred thousand sesterces, instead of eight hundred thousand, and making up the amount for those who did not possess it. He often gave largess to the people, but usually of different sums: [...] In times of scarcity too he often distributed grain to each man at a very low figure, sometimes for nothing, and he doubled the money tickets.'

(Suet. Aug. 41).

Thanks to the recognition of such patterns we can claim that canonical paragraph 61 (the last paragraph) of Sallust's Bellum Catilinae actually contains two symmetrically built-up paragraphs; cf. (11) below. Both paragraphs included in canonical paragraph 61 open up with a general claim (sed confecto proelio tum vero cerneres, quanta animi vis fuisset [...] and Neque tamen exercitus populi Romani laetam aut incruentam victoriam adeptus erat); then, the supportive arguments follow, the first of them in both cases introduced by nam, the second in both cases by autem, and the others by various connectors and particles. The last argument in each paragraph is accompanied by a conclusion introduced by ita.

(11) Sed confecto proelio tum vero cerneres quanta audacia quantaque animi vis fuisset in exercitu Catilinae.

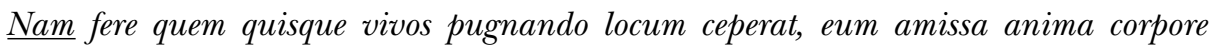
tegebat.

Pauci autem, quos medios cohors praetoria disiecerat, paulo divorsius, sed omnes tamen advorsis volneribus conciderant.

Catilina vero longe a suis inter hostium cadavera repertus est, paululum etiam spirans ferociamque animi, quam habuerat vivos, in voltu retinens.

Postremo ex omni copia neque in proelio neque in fuga quisquam civis ingenuus captus est:

ita cuncti suae hostiumque vitae iuxta pepercerant.

Neque tamen exercitus populi Romani laetam aut incruentam victoriam adeptus erat.

Nam strenuissumus quisque aut occiderat in proelio aut graviter volneratus discesserat.

Multi autem, qui e castris visundi aut spoliandi gratia processerant, volventes hostilia cadavera amicum alii pars hospitem aut cognatum reperiebant;

fuere item, qui inimicos suos cognoscerent.

Ita varie per omnem exercitum laetitia, maeror, luctus atque gaudia agitabantur.

'When the battle was ended it became evident what boldness and resolution had pervaded Catiline's army. For almost every man covered with his body, when life was gone, the position which he had taken when alive at the beginning of the conflict. A few, indeed, in the centre, whom the praetorian cohort had scattered, lay a little apart from the rest, but the wounds even of these were in front. But Catiline was found far in advance of his men amid a heap of slain foemen, still breathing slightly, and showing in his face the indomitable spirit which had animated him when alive. Finally, out of the whole army not a single citizen of free birth was taken during the battle or in flight, showing that all had valued their 
own lives no more highly than those of their enemies. But the army of the Roman people gained no joyful nor bloodless victory, for all the most valiant had either fallen in the fight or come off with severe wounds. Many, too, who had gone from the camp to visit the field or to pillage, on turning over the body of the rebels found now a friend, now a guest or kinsman; some also recognized their personal enemies. Thus the whole army was variously affected with sorrow and grief, rejoicing and lamentation.'

(SAll. Catil. 61).

\section{Other means of signaling the beginning of a new section}

"Although indentation or any other graphical means might not have been employed systematically in ancient Latin texts, there are other means of signaling the beginning of a new section (i.e. a paragraph as well). For example, connectors and particles are frequently used at the beginning of the next paragraph to indicate how the upcoming paragraph is related to the previous context: cf. sed and neque tamen above in (11), igitur in (7); also, words such as praeterea, porro, deinde, etc. are frequently employed in this function. In other cases, the paragraph opens with its main topic (e.g. Gaius Octavius pater and Atia in (5); graves ignominias cladesque in (6), and liberalitatem in (10)) or anaphora (e.g. ea gens in (2) and haec omnia in (8)). In addition, some genres and authors have their own formulas; for example, in annalistic historiography a new section (usually as well as paragraph) starts with the indication of consuls; Lucretius has a set of formulas introducing a new argument/instance, e.g. huc accredit uti (Lucr. 1,192), nunc age (Lucr. 1,265)."As I have noted elsewhere (Ctibor, in print), in speeches, a new paragraph is frequently signaled by the vocative; cf. (12), Catilina's speech as portrayed by Sallust. I quote only an abbreviated English translation here; note the position of the vocatives milites.

'I am well aware, soldiers (milites), that words do not supply valour, and that a spiritless army is not made vigorous, or a timid one stout-hearted, by a speech from its commander. $[\ldots]$

You know perfectly well, soldiers (milites), how great is the disaster that the incapacity and cowardice of Lentulus have brought upon himself and us [...]

Moreover, soldiers (milites), we and our opponents are not facing the same exigency. We are battling for country, for freedom, for life; [...]

When I think on you, soldiers (milites), and weigh your deeds, I have high hopes of victory. [...]'

(SAll. Catil. 58).

In some cases, the end of a paragraph is also signaled. Oakley (2009: p. 202) notes that "epigrammatic sententiae are the most famous characteristic of the declamatory and pointed style, serving often to mark the climax of an argument or the end of a paragraph". 


\section{Conclusions}

In this article, I have tried to show that although paragraphs were not graphically marked in ancient texts, ancient authors did write in paragraphs: this can be concluded from the organization of information into "paragraphs", from recurring text patterns, and from other than graphical means of signaling the beginning of a new section. Indentation is only a modern graphical signal to which modern readers are accustomed, but not an indispensable one. To see more clearly that indentation is a mere convention, consider also the fact that modern editors mostly indent in Lucretius, but they do not in mock-didactic Ovid (the reason being that you can easily indent in hexameters, but it is unaesthetic in elegiacs).

Because ancient authors wrote in paragraphs, I believe modern editors have a right to make use of indentation and divide texts into paragraphs, similarly as they make use of modern punctuation. As follows from Section 2 above, however, they should do so only after very careful consideration; otherwise, they may do more harm than good.

The scope of this article is still very limited and the study of paragraphs offers many blank spaces. I focused only on two very simple schemes. There are many other schemes, some of them much more complicated with a number of variables. It might be interesting to study the interrelatedness between paragraphs and rhythm. There are also unanswered questions of style: which paragraphs are typical of a given author, a given genre, a given type of text (narrative, description, exposition, etc.).

\section{Bibliography}

\section{Primary sources}

Carter, J. M. (Ed.). (1982). Suetonius: Divus Augustus. Bristol: Bristol Classical Press.

All the other texts and translations are taken from the Loeb Classical Library.

\section{Secondary sources}

Blommaert, J. (2009). Discourse. A Critical Introduction ( $5^{\text {th }}$ print.). Cambridge: Cambridge University Press.

Ctibor, M. (in print). Pragmatic Functions of the Latin Vocative.

Daneš, F. (1968). Typy tematických posloupností v textu (na materiále českého textu odborného) [Types of 'Thematic Progression' in Text (Based on an Analysis of Czech Technical Texts)]. Slovo a slovesnost, 29, 125-141.

Daneš, F. (1994). Odstavec jako centrální jednotka tematicko-kompoziční výstavby textu (na materiále textů výkladových) [The Paragraph - a Central Unit of the Thematic and Compositional Build-up of Expository Discourses]. Slovo a slovesnost, 55, 1-17.

Hoffmann, R. (2010). Latin Word Order Revisited: Information Structure of Topic and Focus. In 
P. Anreiter, \& M. Kienpointner (Eds.), Latin Linguistics Today. Akten des 15. Internationalen Kolloquiums zur Lateinischen Linguistik, Innsbruck 4-9 April 2009 (pp. 267-280). Innsbruck: Institut für Sprachen und Literaturen der Universität Innsbruck.

Kroon, C. (1995). Discourse particles in Latin. A study of nam, enim, autem, vero and at. Amsterdam: J. C. Gieben.

Kroon, C. (2011). Latin Particles and the Grammar of Discourse. In J. Clackson (Ed.), A Companion to the Latin Language (pp. 176-195). Malden: Wiley-Blackwell.

Kroon, C. (2014). Causality, Coherence and Latin 'Connectives': A Discourse Pragmatic Approach. In A. Morel-Alizon, \& J.-F. Thomas (Eds.), La causalité en Latin (pp. 67-85). Paris: L'Harmattan. Oakley, S. P. (2009). Style and Language. In A. J. Woodman (Ed.), The Cambridge Companion to Tacitus (pp. 195-211). Cambridge: Cambridge University Press.

Spevak, O. (2010). Constituent Order in Classical Latin Prose. Amsterdam - Philadelphia: John Benjamins.

Wingo, E. O. (1972). Latin Punctuation in the Classical Age. The Hague - Paris: Mouton.

Mgr. Michal Ctibor / michal.ctibor@ff.cuni.cz

Institute of Greek and Latin Studies

Charles University, Faculty of Arts

Nám. Jana Palacha 2, 11638 Prague 1, Czech Republic 
